\title{
Sapelenin G, a new acyclic triterpenoid from the stem bark of Entandrophragma cylindricum
}

\author{
D. NGNOKAM ${ }^{1 *}$, J. M. NUZILLARD $^{2}$ and G. MASSIOT ${ }^{3}$ \\ ${ }^{1}$ Faculty of Science, Department of Chemistry, University of Dschang. P.O. Box 67 Dschang, Cameroon. \\ ${ }^{2}$ Laboratoire de Pharmacognosie. UMR. 6013 B.P. 1039, 51097 Reims cedex 2, France. \\ ${ }^{3}$ Institut de Recherche Pierre Fabre, Centre de recherche sur les Substances Naturelles, Bureaux de l'Espace- \\ 3, Rue Ariane-Parc Technologique du Canal-31527 Ramonville, France. \\ * Corresponding author, Tel: (237) 96932925, E-Mail: dngnokam@yahoo.fr
}

\begin{abstract}
A new acyclic triterpenoid, sapelenin G (1) was isolated from the stem bark of Entandrophragma cylindricum. Its structure was determined from spectroscopic data and by chemical transformation.

(C) 2007 International Formulae Group. All rights reserved.
\end{abstract}

Keywords: Entandrophragma cylindricum, sapelenin; Meliaceae, acyclic triterpenoid.

\section{INTRODUCTION}

The genus Entandrophragma (Casimir de Candole) belongs to the family Meliaceae and consists of more than 1400 species (Kamga, 1980). It is widespread on the African continent, south of the Sahara (Aubreville, 1950) and occupies a prominent position in traditional African medicine (Daziel, 1937; Irvine, 1961). Five species are known in Cameroon (Letouzey, 1985) and among which Entandrophragma cylindricum Sprague (known locally as Sapele Mahogany) has already been the object of biological and chemical investigations (Akisanya et al., 1960; Chan et al., 1970; 1971; Daniewski et al., 1996).

In searching for antifeedants compounds against storage pests, we reported in previous articles (Ngnokam et al., 1993; 1994; 1995; 2005) the isolation and the structural determination of a number of steroids, flavonoids and acyclic triterpenoids from Entandrophragma cylindricum. Continuing the study of the plant, we were gratified to find a new acyclic triterpenoid, named sapelenin $G(\mathbf{1})$, for which the structure

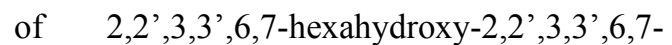
hexahydrosqualene was proposed.

\section{MATERIALS AND METHODS}

General. Mp: uncorr.; IR: NaCl. NMR spectra were recorded at $125 \mathrm{MHz}$ for ${ }^{13} \mathrm{C}$ and $300 \mathrm{MHz}$ for ${ }^{1} \mathrm{H}$. Chemical shifts are given in $\delta$ value (ppm) with TMS as internal standard. EI-MS was measured at $70 \mathrm{eV}$. TLC was carried out on silica gel. The triterpenoid compound was detected by spraying with $50 \%$ solution of $\mathrm{H}_{2} \mathrm{SO}_{4}$ in $\mathrm{H}_{2} \mathrm{O}$ followed by heating.

Plant material. The bark of Entandrophragma cylindricum was collected from Awae (Cameroon). A voucher specimen is deposited at the Cameroon National Herbarium, Yaounde.

Extraction and isolation. The air-dried and finely ground material $(10 \mathrm{~kg})$ was extracted with n-hexane $\left(\begin{array}{ll}15 & 1\end{array}\right)$ at room temperature. The residue (powder) was then extracted with $\mathrm{CH}_{2} \mathrm{Cl}_{2}\left(\begin{array}{ll}10 & 1\end{array}\right)$ at room temperature. The dry $\mathrm{CH}_{2} \mathrm{Cl}_{2}$ extract $(33 \mathrm{~g})$ was chromatographed on a silica gel (Merck silica gel 60) column using a gradient elution with $\mathrm{CH}_{2} \mathrm{Cl}_{2}-\mathrm{MeOH}$ (from 9.5:0.5, via 8:2 to 
6:4) and collecting $150 \mathrm{ml}$ fractions. Fractions $211-216$ were pooled together and dried to give a brown gum (133 mg), which was rechromatographed repeatedly on silica gel using the same solvent system to yield sapelenin G (1) (35 mg).

Sapelenin $G$ (1) isolated as an oil (Found: C, 69.60; H, 11.40; $\mathrm{C}_{30} \mathrm{H}_{56} \mathrm{O}_{6}$ requires C, 70; H, 11); $[\alpha]_{\mathrm{D}}{ }^{23}+8^{\circ}\left(\mathrm{CHCl}_{3}\right.$, c 3); IR $v_{\max }$ $(\mathrm{NaCl}) \mathrm{cm}^{-1}: 3480(\mathrm{OH}), 1660(\mathrm{C}=\mathrm{C})$; EIMS $\mathrm{m} / \mathrm{z}$ (\% int. rel.): 512 (0.3), 476 (3), 209 (30), 143 (40), 79 (100); ${ }^{1} \mathrm{H}$ NMR $\left(\mathrm{CDCl}_{3}\right): \delta 5.20$ (m, (3H), H-7', H-11'and H-11), 3.40 (m, 3H, H-3', H-3, and H-7), 1.70 (s, Me-14', Me-14), 1.68 (s, Me-15'), 1.20, 1.18 (Me-1t, Me-1t' and Me-14), 1.12 (Me-1c and Me-1c').

\section{Preparation of the triacetate (4):}

This compound was prepared by dissolving sapelenin $\mathrm{G}(15 \mathrm{mg})$ in $\mathrm{CH}_{2} \mathrm{Cl}_{2}(10$ $\mathrm{ml})$, and adding acetic anhydride $(3 \mathrm{ml})$ and a catalytic amount of DMAP $(5 \mathrm{mg})$. The mixture was stirred overnight (15 hrs) at room temperature $\left(20^{\circ} \mathrm{C}\right) . \mathrm{CuSO}_{4}$ solution $(10 \%)$ was added and then the organic phase was washed with a saturated $\mathrm{NaHCO}_{3}$ solution (10 ml) and dried over $\mathrm{Na}_{2} \mathrm{SO}_{4}$. Co-evaporation with toluene was then performed and (4) was the sole compound obtained. Mp. 118-119 $[\alpha]_{\mathrm{D}}{ }^{23}+10^{\circ}\left(\mathrm{CHCl}_{3}\right.$, c 2); IR $v_{\max }(\mathrm{NaCl}) \mathrm{cm}^{-1}$ : $3480(\mathrm{OH}), 1740$ (-OCOMe), $1660(\mathrm{C}=\mathrm{C}) ;{ }^{1} \mathrm{H}$ NMR $\left(\mathrm{CDCl}_{3}\right): \delta 5.15(\mathrm{~m}, 3 \mathrm{H}, \mathrm{H}-7$ ', H-11'and H-11), 4.80 (m, 3H, H-3', H-3 and H-7), 1.60 (s, Me-14', Me-15' and Me-15), 2.18 (s, 3 x Ac), 1.25 (s, Me-1t' and Me-1t), 1.23 (s, Me1c' and Me-1c), 1.21 (Me-14).

\section{Preparation of tri-acetonide (5)}

This compound was prepared by dissolving sapelenin $\mathrm{G}$ (12 $\mathrm{mg})$ in acetone (10 $\mathrm{ml}$ ), adding three equivalent of 2,2dimethoxypropane $(1.5 \mu \mathrm{l})$ and a catalytic amount of $p$-toluenesulphonic acid $(5 \mathrm{mg}$ ). The reaction was complete at room temperature $\left(20^{\circ} \mathrm{C}\right)$ in 25 minutes. Hexane $(10$ $\mathrm{ml}$ ) was added and the organic phase was washed with saturated $\mathrm{NaHCO}_{3}(5 \mathrm{ml})$ and dried over $\mathrm{Na}_{2} \mathrm{SO}_{4}$. Removal of the solvent using the evaporating rotator, gave the triacetonide as a clear oil. $[\alpha]_{\mathrm{D}}{ }^{23}+9^{\circ}\left(\mathrm{CHCl}_{3}, \mathrm{C}\right.$ 2); IR $v_{\max }(\mathrm{NaCl}) \mathrm{cm}^{-1}: 1660(\mathrm{C}=\mathrm{C}), 1215(\mathrm{C}-$ $\mathrm{O}) ;{ }^{1} \mathrm{H}$ NMR $\left(\mathrm{CDCl}_{3}\right): \delta 5.15(\mathrm{~m}, 3 \mathrm{H}, \mathrm{H}-7$ ', $\mathrm{H}-$ 11 'and $\mathrm{H}-11)$, 3.62-3.70 (m, 3H, H-3', H-3 and H-7), 1.60-1.70 (s, Me-14', Me-15' and
Me-15), 1.10-1.32 (s, Me-1t', Me-1t, Me-1c', $\mathrm{Me}-1 \mathrm{c}$ and $\mathrm{Me}-14$ ), 1.34-1.42 (s, 3 x O$\left.\mathrm{C}(\mathrm{Me})_{2}-\mathrm{O}\right)$.

\section{RESULTS AND DISCUSSION}

A novel acyclic triterpenoid (1) was obtained from the methylene chloride extract and purification was achieved by vacuum liquid chromatography and subsequent silica gel column chromatography. Investigation of the polar fractions led to the isolation of sapelenin G (1). Its structure was determined by interpretation of its spectral data, mainly ${ }^{1} \mathrm{H}$ and ${ }^{13} \mathrm{C}$ NMR as well as by comparison with the literature values (Ngnokam et al., 1993; 1995). Sapelenin $\mathrm{G}$ was isolated as a colourless oil. $[\alpha]_{\mathrm{D}}{ }^{23}+8^{\circ}\left(\mathrm{CHCl}_{3}, c\right.$ 3). Its mass spectrum gave the $\mathrm{M}^{+}$at $\mathrm{m} / \mathrm{z} 512$ $\left(\mathrm{C}_{30} \mathrm{H}_{56} \mathrm{O}_{6}\right)$. The study of its IR spectrum indicated the presence of hydroxyl and carbon-carbon double bonds (see Experimental). The ${ }^{13} \mathrm{C}$ NMR displayed 30 carbons: eight methyls, 10 methylenes, three methynes bearing oxygen, three $\mathrm{sp}^{2}$ methynes and six quaternary carbons including three $\mathrm{sp}^{2}$, and three bearing oxygen. This was confirmed by the ${ }^{1} \mathrm{H}$ NMR spectrum in which eight singlet methyls were observed, including three vinylic, and three attached to carbon bearing oxygen. The $-\mathrm{CH}(\mathrm{OH})$ - proton appeared at $\delta 3.40$ and the vinyl proton (together) at $\delta 5.15(3 \mathrm{H})$. Comparison of the ${ }^{13} \mathrm{C}$ NMR data of sapelenin G (1) with those of sapelenin C (2) and squalene (3) indicated the absence of an intact farnesyl or geranylgeranyl fragment. This was supported by the mass spectrum in which the ions at $\mathrm{m} / \mathrm{z} 205$ and 271 , corresponding to the farnesyl or geranyl-geranyl radical cation respectively were not observed. The formation of the triacetate compound (4), on treatement of (1) with DMAP, acetic anhydride in methylene chloride, indicated that there are three secondary hydroxyl group since the ${ }^{13} \mathrm{C}$ spectrum showed six additional carbon signals ( $\delta 171.1,171.2$ and 20.9) corresponding to the acetyl groups. The ${ }^{1} \mathrm{H}$ NMR of (4) also showed three additional methyl signals and a small downfield shift of the $\mathrm{CH}(\mathrm{OR})$ protons $(\delta$ 4.80). The formation of tri-acetonide (5), on treatment of (1) with 2,2dimethoxypropane and $p$-toluenesulphonic acid in acetone, indicated that there were three vicinal diols since the ${ }^{13} \mathrm{C}$ chemical shift of 
acetal carbons $(\delta 106.5)$ clearly revealed that the acetonide had five-membered rings (Buchanan et al., 1980). The ${ }^{1} \mathrm{H}$ NMR of (5) showed six additional methyl signals and a small downfield shift of the $\mathrm{CH}(\mathrm{OR})$ protons ( $\delta 3.62-3.70)$. The carbons involved in acetonide formation were readily identified by downfield shifts of 5-7 ppm (Table). The above evidence suggests that sapelenin $G(\mathbf{1})$ is a squalene derivative in which three double bonds are hydroxylated. The relative position of hydroxyl group in (1) follows from the comparison of the ${ }^{13} \mathrm{C}$ data of (1) to those of (2) and (3), and from correlations observed in an $\mathrm{HMBC}$ experiment, as in the Figure below.

Table: ${ }^{13} \mathrm{C}$ NMR data of compounds (1), (2), (3) and (5) in $\mathrm{CDCl}_{3}$

\begin{tabular}{|c|c|c|c|c|c|c|c|c|c|}
\hline $\mathrm{N}^{\circ} \mathrm{C}$ & 1 & 2 & 3 & 5 & $\mathrm{~N}^{\circ} \mathrm{C}$ & 1 & 2 & 3 & 5 \\
\hline $1 \mathrm{t}^{\prime}$ & 26.3 & 26.2 & 25.6 & 25.8 & $1 \mathrm{t}$ & 26.3 & 26.2 & 25.6 & 26.0 \\
\hline $1 c^{\prime}$ & 23.3 & 23.3 & 17.6 & 22.9 & $1 \mathrm{c}$ & 23.3 & 23.3 & 17.6 & 22.9 \\
\hline $2^{\prime}$ & $73 ; 1$ & 73.0 & 131.1 & 80.2 & 2 & 73.2 & 73.3 & 131.1 & 80.2 \\
\hline 3 , & 78.1 & 78.0 & 124.4 & 82.9 & 3 & 78.8 & 78.7 & 124.4 & 83.9 \\
\hline $4^{\prime}$ & 29.7 & 29.0 & 26.7 & 27.7 & 4 & 25.2 & 24.7 & 26.7 & 22.8 \\
\hline 5 , & 36.6 & 36.6 & 39.6 & 36.3 & 5 & 32.9 & 34.4 & 39.7 & 35.2 \\
\hline $6^{\prime}$ & 134.7 & 134.0 & 134.8 & 134.2 & 6 & 74.4 & 73.5 & 134.8 & 79.4 \\
\hline 7' & 124.9 & 124.7 & 124.2 & 124.9 & 7 & 79.1 & 79.6 & 124.8 & 81.0 \\
\hline $8^{\prime}$ & 26.3 & 26.3 & 26.6 & 26.6 & 8 & 29.4 & 27.5 & 26.6 & 27.8 \\
\hline 9' & 39.5 & 39.0 & 39.7 & 39.7 & 9 & 36.8 & 36.2 & 39.7 & 36.8 \\
\hline $10^{\prime}$ & 134.8 & 134.6 & 135.0 & 134.7 & 10 & 134.9 & 134.8 & 135.0 & 135.1 \\
\hline $11^{\prime}$ & 124.8 & 124.6 & 124.3 & 124.8 & 11 & 124.9 & 124.2 & 123.3 & 124.2 \\
\hline $12^{\prime}$ & 28.0 & 27.9 & 28.2 & 28.2 & 12 & 28.0 & 28.0 & 28.2 & 28.3 \\
\hline $14^{\prime}$ & 15.8 & 15.8 & 16.0 & 16.0 & 14 & 23.1 & 22.3 & 16.0 & 22.9 \\
\hline \multirow[t]{2}{*}{$15^{\prime}$} & 15.8 & 15.8 & 15.9 & 16.0 & 15 & 15.9 & 15.8 & 15.9 & 16.0 \\
\hline & & & & & $\mathrm{MeCO}-(\mathrm{Me})_{2} \mathrm{CO}_{2}$ & & $171.1,21.1$ & & $106.6,27.7-28.5$ \\
\hline
\end{tabular}<smiles>[R20]C(CCC(C)=CCCC(C)=CCCC=C(C)CCC(C(C)(C)O)C([R12])(O)CCC([R20])C(C)(C)O)C(C)(C)O</smiles>
(1) $\mathrm{R}=\mathrm{R}_{1}=\mathrm{H}$
(2) $\mathrm{R}=\mathrm{H}, \mathrm{R}_{1}=\mathrm{OAc}$
(4) $\mathrm{R}=\mathrm{R}_{1}=\mathrm{OAc}$
(5) $\mathrm{RR} 1=(\mathrm{CH} 3)_{2} \mathrm{C}<\mathrm{O}$<smiles>CC(C)=CCCC(C)=CCCC(C)=CCCC=C(Br)CCC=C([Al])CCC=C(C)C</smiles>

(3) 


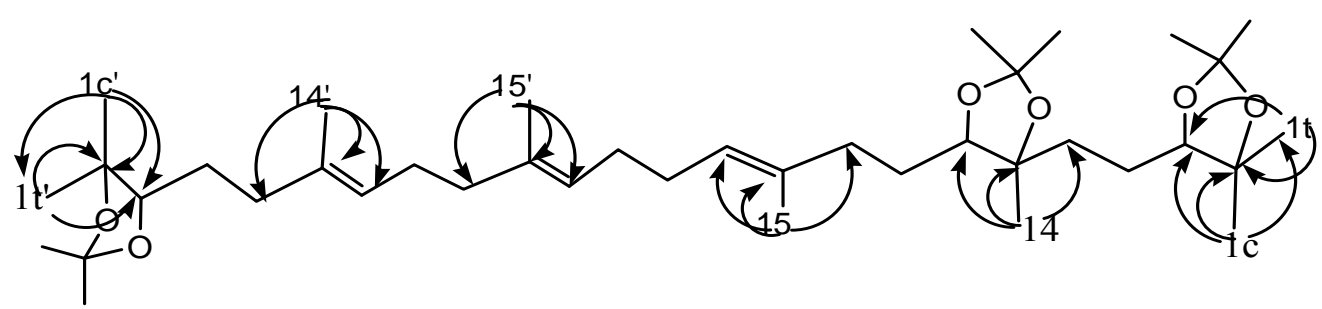

Figure: HMBC correlations observed for compound $\mathbf{5}$

\section{REFERENCES}

Akisanya A, Bevan CWL, Hirst J, Halsall TG, Taylor DAH. 1960. West Africans timbers. Part III. Petroleum extracts from the genus Entandrophragma. J. Chem. Soc. (C), 3827-3829.

Aubreville A. 1950. Flore Forestière Soudano-guinéenne. Societé d'Editions Géographiques, Maritimes et Coloniales: Paris ; 377.

Buchanan JG, Chacon-Fuertes ME, Edgar AR, Moorhouse SJ, Rawson ID, Wightman RH. 1980. Assignment of ring size in isopropylidene acetals by ${ }^{13} \mathrm{C}$ N.M.R. Tetrahedron Letters, 21: 17931796.

Chan WR, Taylor DR, Yee TH. 1970. Triterpenoids from Entandrophragma cylindricum Sprague. Part I. Structure of sapelins A and B. J. Chem. Soc. (C), 311314.

Chan WR, Taylor DR, Yee TH. 1971. Triterpenoids from Entandrophragma cylindricum Sprague. Part II. Structure of sapelins C, D, E and F. J. Chem. Soc. (C), 2662-2667.

Daniewski WM, Anezewski W, Gumulka M, Danikiewicz W, Jacobsson U, Norin T. 1996. Sesquiterpenoid constituents of Entandrophragma cylindricum. Phytochemistry, 43: 811-814.

Daziel JM. 1937. The useful plants of West Tropical Africa. Crown Agents: London.

Irvine FR. 1961. Woody Plants of Ghana. Oxford University Press: London; 878.
Kamga C. 1980. Contribution à l'étude chimique des plantes médicinales du Cameroun : Carapa procera (Méliacée). Thèse de Doctorat de $3^{\text {ème }}$ cycle, Université de Yaoundé, Yaoundé, p.13.

Letouzey R. 1985. Notice de la carte géographique du Cameroun. Int. de la Carte Géog., Int. de Vég. : Toulouse ; 4: 98.

Ngnokam D, Massiot G, Nuzillard JM, Connolly JD, Tsamo E, Morin C. 1993. Sapelenins A, B and C, acyclic triterpenoids from the stem bark of Entandrophragma cylindricum. Phytochemistry, 34: 1603-1607.

Ngnokam D, Massiot G, Nuzillard JM, Tsamo E. 1994. 2R,3S-trans-pubeschin from Entandrophragma cylindricum. Phytochemistry, 37: 529-531.

Ngnokam D, Massiot G, Nuzillard JM, Tsamo E. 1994. Steroids and terpenoids from the bark and the wood of Entandrophragma cylindricum. 1994. Bull. Chem. Soc. Ethiop., 8: 15-20.

Ngnokam D, Massiot G, Bliard C, Tsamo, E. 1995. Sapelenin D, a new acylic triterpenoid from the stem bark of Entandrophragma cylindricum. Natural Product Letters, 5: 289-293.

Ngnokam D, Nuzillard JM, Bliard C. 2005. Sapelenin E and F: new acyclic triterpenoids from the stem bark of Entandrophragma cylindricum. Bull. Chem. Soc. Ethiop., 19: 227-231. 